\title{
Introduction to No. 1, Part two: Developing Moral Competence, Perfecting Selfhood, Practicing Forgiveness
}

\author{
Filip Bardziński \\ (Adam Mickiewicz University in Poznań, fmbardzinski@gmail.com) \\ Joanna Dutka \\ (Adam Mickiewicz University in Poznań, joannadutka7@gmail.com)
}

The growing tensions of Western civilization do not seem to cease or lighten up. The coming presidential elections in the United States do prove that even well-established and culturally rich societies are becoming even more divided between neoliberal and conservative ideologies. Public debates tend to become overwhelmed by not only biased opinions, presented as objective facts, but also fall under the spell of populism and cheap manipulation. In such an atmosphere, the need for developing moral and democratic competence is as obvious - and as vital - as never before.

Thanks to many authors, whose research is consecrated to the aforementioned notion of developing democratic and moral dispositions, we are hereby able to present a multifaceted study of how these vital abilities are developing in different societies and how it is possible not only to develop them, but also prepare efficient ways of preserving one's moral capabilities in even most dire and unwelcoming environment.

In the works of Sofia Karamavrou et al. (2016), Eka Kaznina (2016), Zhu Hai-Long (2016), Martina Reinicke (2016), and Qian Zhang \& Stephen J. Thoma (2016), the notion of developing moral capacities is addressed implicitly, mainly by adapting the Konstanz Method of Dilemma Discussion $\left(\mathrm{KMDD}^{\circledR}\right)$ and the Moral Jugdment Test $\left(\mathrm{MJT}^{\circledR}\right)$ elaborated by Georg Lind to the cultural, social, and political environments of Greece, Russia, Georgia, China, and the United States. The use of empirical methods proves that it is possible to develop intersubjectively convincing conclusions in the field of developmental psychology and moral development theory. Furthermore, the wide range of cultural backgrounds, taken into account by the authors, disproves heavily the somewhat popular belief that there is no common ground for intercultural ethics. Parting from simple moral relativism, the notion of developing moral and democratic competence prove that in a pluralist world, in which different beliefs and ideologies compete, it is possible to affirm a universal moral standard, despite cultural, social, and political differences.

The abovementioned notion of an existing universal moral standard, that rejects simple moral tyranny in favor of embracing cultural and political differences by emphasizing the ability to rationally justify one's beliefs, has 
deep philosophical roots, as shown by Anna Malitowska and Mateusz Bonecki (2016), Klementyna Chrzanowska (2016), Katarzyna Gan-Krzywoszyńska and Piotr Leśniewski (2016). Such noble and well-established philosophers, such as Stanley Cavell, John Dewey, Reyes Mate, and Paul Ricoeur have consecrated - explicitly and implicitly - a large part of their intellectual work to the notion of how morality and it's development may be strengthened and fortified. J. Dewey's pedagogy and epistemology, as shown by A. Malitowska and M. Bonecki, defend the notion that the "competences of using theoretical conceptual frameworks and conducting scientific inquiry play crucial role in Dewey's educational ideology of progressivism since they provide basic tools for critical reconsideration and revision of common sense beliefs" (Malitowska \& Bonecki 2016, p. 185). The capability to critically verify and consciously justify one's beliefs - parting from the common-sense paradigm in favor of moral autonomy and selfhood - is what establishes a stable foundation for social understanding in the forms of social recognition, and the ability to practice forgiveness. In effect, developing moral and democratic competence gives the possibility to develop not only more understanding and less violent societies, but also to promote a perfectionist model of human nature, that embraces the Aristotelian notion of justice as complete virtue, since a person who "exercise his virtue not only in himself but towards his neighbor also" has reached his full potential, for "many man can exercise virtue in their own affairs, but not in their relations to their neighbor" (Aristotle 1999, p. 73).

For the Polish-speaking readers, we have included a bonus: the translated work of Grant Farred, devoted to reading the work of Jacques Derrida in the context of influences from Frantz Fanon.

Developing moral and democratic competences is the subject of the most recent work of Georg Lind How to teach Morality. Promoting Deliberation and Discussion, Reducing Violence and Deceit, which was critically received by Semíramis Llanos Cobos and Ewa Nowak.

Finally, we have the pleasant possibility to announce the upcoming conference "Moral competence: A brand new research topic in cognitive psychology, ethics and law," organized jointly by Universität Konstanz, Adam Mickiewicz University in Poznań, Jagiellonian University in Cracow, and Vilniaus Universitetas on 29-30 September 2017. More informations, as well as the conference and workshops programs and registration forms can be found at the conference webpage: https://moralcompetenceconference2017.wordpress.com/. We're hoping to meet at the conference venue in Poznań!

\section{Literature}

Aristotle. 1999. Nicomachean Ethics. Transl. W. D. Ross. Kitchener: Batoche Books. 
Chrzanowska, K. 2016. "Searching for Selfhood: Ricoeur's Recognition and Cavellian Acknowledgment." Ethics in Progress, Vol. 7(1): 186-200.

Gan-Krzywoszyńska, K. \& P. Leśniewski. 2016. „Przemoc hermeneutyczna. 0 analogicznej rekonstrukcji obecności." Ethics in Progress, Vol. 7(1): 201-214.

Karamavrou, S., et al. 2016. "Moral Competence, Personality, and Demographic Characteristics: A Comparative Study." Ethics in Progress, Vol. 7(1): 123-138.

Kaznina, E. 2016. "Influence of Cultural and Historical Context on the Moral Competence in Modern Society (in Terms of Georgia and Russia)." Ethics in Progress, Vol. 7(1): 139-161.

Malitowska, A. \& M. Bonecki. 2016. "Common Sense and Scientific Inquiry: Remarks on John Dewey's Philosophy of Educational Progressivism." Ethics in Progress, Vol. 7(1): 172-185.

Reinicke, M. 2016. "Inclusion: The Best Mean Against Violence, Deceit and Force." Ethics in Progress, Vol. 7(1): 215-227.

Zhang, Q. \& S. J. Thoma. 2016. "An Empirical Cross-Cultural Study of Moral Judgment Development in Mainland China." Ethics in Progress, Vol. 7(1): 228-245.

Zhu, Hai-Long. 2016. “An Empirical Research about Xinjiang Minority College Students' Value Recognition in Inner-Mainland's Universities of China." Ethics in Progress, Vol. 7(1): 162-171. 
Filip Bardziński \& Joanna Dutka

(Adam Mickiewicz University in Poznań fmbardzinski@gmail.com, joannadutka7@gmail.com)

\section{Introduction to No. 2: Developing Moral Competence, Perfecting Selfhood, Practicing Forgiveness}

Abstract: The introduction to Ethics in Progress Special Issue, Vol. 7(1), No. 2 is given, with brief exposés on the articles present in the section.

Keywords: KMDD ${ }^{\circledR}$, Paul Ricoeur, selfhood, moral and democratic competence, John Dewey

Ethics in Progress (ISSN 2084-9257). Vol. 7 (2016). No. 1, Art. \#9, pp. v-viii.

doi: 10.14746/eip.2016.1.ii 